\title{
KOMPETISI DAN PENUNDUKAN BIROKRASI PADA REZIM KNOWLEDGE-BASED DEVELOPMENT
}

\author{
Caroline Paskarina \\ Program Studi Ilmu Politik FISIP Universitas Padjadjaran \\ E-mail: cpaskarina@yahoo.com
}

\begin{abstract}
ABSTRAK. Tulisan ini ingin mengungkapkan bagaimana pembangunan sebagai praktik kekuasaan berlangsung atas dasar klaim kebenaran tertentu yang menjadi instrumen untuk mempertahankan kemapanan. Dengan menggunakan konsep kekuasaan produktif dari Foucault (2002), yang dioperasionalisasikan dengan metode analisis diskursus, akan ditunjukkan bagaimana praktik pembangunan diarahkan untuk tunduk pada rezim knowledge management. Penguasaan akan pengetahuan dan kemampuan untuk mengelola berbagai informasi secara sistematis menjadi sangat strategis untuk menjamin keberlanjutan pembangunan. Masuknya rezim ini dalam pembangunan menjadi dasar argumen untuk mendorong perubahan cara kerja birokrasi. Birokrasi sebagai institusi yang berwenang mengalokasikan sumber-sumber daya didisiplinkan melalui penetapan berbagai standar agar mampu mengelola data dan informasi untuk pengambilan keputusan. Penundukan birokrasi pada rezim knowledge management untuk berinovasi mengubah praktik pembangunan menjadi lebih terukur, tapi di sisi lain, juga menjebak birokrasi pada rigiditas prosedur pengelolaan pengetahuan, sehingga mengabaikan makna utama pembangunan sebagai penciptaan kesejahteraan bukan sekedar pencapaian angka.
\end{abstract}

Kata kunci: kompetisi, penundukan birokrasi, knowledge-based development

\section{COMPETITION SUBMISSION AND BUREAUCRACY REGIME ON KNOWLEDGE -BASED DEVELOPMENT}

\begin{abstract}
This paper wants to reveal how development as power practice is operated based on certain regime of truth as the instrument to preserve established regime. By using concept of productive power popularized by Foucault, operationalized through method of discourse analysis, this paper analyzes how pratice of development is directed to subject to regime of knowledge management. The mastery of knowledge and ability to manage various information systematically is very strategic to ensure the sustainability of welfare creation. The emerging of this regime into development became the basic argument to transform method of work in bureaucracy. Bureaucracy as the institution authorized to allocate resources to work with innovation in managing data and information for decision making. Subjectivation of bureaucracy to regime of knowledge in order to improve their competitiveness to innovate transforms development into more measurable process, but in other side, it also traps bureaucracy into rigidity of knowledge management procedure, making them ignore the main meaning of development as welfare creation, not just the achievement of number.
\end{abstract}

key words: competition, subjectivation, bureaucracy, knowledge-based development

\section{PENDAHULUAN}

Dalam berbagai studi tentang praktik pengelolaan urusan publik atau pemerintahan, pembahasan mengenai cara memerintah lebih banyak dijelaskan secara normatif atau teknis. Dalam pandangan ini, kewenangan atau legitimasi formal menjadi dasar bagi negara untuk mengatur hubungan antara manusia dengan berbagai hal, termasuk dalam mengelola berbagai sumber daya untuk kepentingan umum. Sementara itu, dalam pandangan manajerial, cara memerintah justru menjadi sangat teknis karena dipahami sebagai penggunaan berbagai alat atau prosedur untuk mencapai tujuan secara efektif dan efisien.

Konseptualisasi tersebut mengabaikan proses politik di balik kemunculan suatu cara memerintah dan alasan-alasan yang melandasi pilihan terhadap cara tertentu. Sebagai bagian dari praktik kekuasaan, pemerintahan merupakan perwujudan dari bekerjanya suatu sistem pengetahuan tertentu yang menentukan alasan-alasan mengapa perlu ada pengaturan tentang suatu hal, siapa yang berhak mengatur, siapa yang diatur, dan bagaimana cara mengaturnya (Foucault dalam Rose,
O’Malley, dan Valverde, 2006). Karena itu, pilihan terhadap suatu cara memerintah bukan semata persoalan teknis karena penerapan suatu cara tertentu akan mengarah pada pendisiplinan, penundukan, dan kepatuhan terhadap tata aturan yang berlaku dalam cara itu. Dalam proses ini, berlangsung praktik kekuasaan karena ada teknik dan prosedur tertentu yang dirancang untuk mengarahkan perilaku manusia. Pusat perhatiannya bukan pada siapa yang memiliki kewenangan atau dari mana sumber kewenangan itu berasal, tapi mengapa sesuatu hal harus diatur seperti itu.

Cara pandang tersebut sejalan dengan konsep kekuasaan produktif yang dikemukakan oleh Foucault (2002). Kekuasaan produktif, sebagaimana diungkapkan Foucault, berperan sebagai pembentuk realitas yang mendasari pilihan atas mekanisme pengaturan sesuatu hal. Sebagai pembentuk realitas, kekuasaan tidak diidentifikasi dari wujudnya, melainkan dari cara kerjanya. Berbeda dengan teorisasi kekuasaan yang umum dikenal, yang menjadi pusat perhatian bagi kekuasaan produktif adalah mengungkapkan praktikpraktik diskursif di balik pembentukan batasan tentang 
normalitas melalui kategori-kategori yang menentukan bagaimana sesuatu hal diperlakukan. Dalam praktik ini, identitas dan kepatuhan dibentuk atas dasar rezim kebenaran yang berlaku dalam suatu sistem pengetahuan.

Bukan kewenangan yang dipakai untuk mengarahkan perilaku, tapi sistem pengetahuan yang menjadi instrumen kekuasaan untuk membentuk realitas, mengatur relasi manusia dengan berbagai sumber daya, dan mengarahkan perilaku manusia agar sejalan dengan klaim kebenaran yang dinyatakan (Pieterse, 2010). Pengetahuan (knowledge) adalah konstruksi realitas yang membentuk persepsi, agenda, bahkan kebijakan yang dibuat untuk merespon realitas tersebut. Sistem pengetahuan di sini tidak diartikan sempit sebagai produk dari pendekatan ilmiah, tapi merupakan keseluruhan konstruksi tentang realitas, yang menentukan seperti apa realitas didefinisikan, dikelola, dan dijelaskan dalam kaitannya dengan realitas lain(Pieterse, 2010). Penyebaran kekuasaan dapat diungkapkan dengan melacak sistem pengetahuan karena setiap sistem pengetahuan akan menghasilkan ekspresi kepatuhan yang berbeda, yang menjamin terpeliharanya kekuasaan. Semakin berkembangnya kepatuhan berarti semakin tersebar dan bertambahnya lingkup kekuasaan. Dalam konteks ini, gagasan tentang pemerintahan melalui pengetahuan (governing by knowledge) menawarkan alternatif untuk memahami bagaimana sistem pengetahuan dipakai untuk menentukan pengelolaan berbagai urusan publik, termasuk dalam praktik pembangunan.

Studi-studi tentang pembangunan yang telah dilakukan cenderung berfokus pada peran negara sebagai institusi yang mengelola sumber daya dengan berbasis kewenangan. Kemunculan konsep governance mengarahkan perhatian pada birokrasi sebagai aktor strategis yang turut menentukan pengelolaan sumber daya. Birokrasi menjadi operator yang menjalankan kewenangan negara dalam mengelola sumber-sumber daya, dengan menggunakan pengetahuan dan keahlian yang dimilikinya. Proses kalkulasi dan teknokrasi yang digunakan birokrasi untuk mengelola pembangunan merupakan praktik kekuasaan yang beroperasi melalui proses diskursif untuk membentuk klaim kebenaran bagi intervensi negara.

Tapi, berbeda dengan studi-studi lainnya yang menempatkan birokrasi sebagai subjek yang membentuk diskursus, tulisan ini justru ingin mengungkapkan praktik kekuasaan di balik subjektivasi birokrasi melalui diskursus kompetisi. Diskursus kompetisi muncul sebagai bagian dari praktik kekuasaan untuk mengubah cara kerja birokrasi. Gagasan reformasi birokrasi berkembang sebagai respon terhadap citra negatif birokrasi sebagai institusi yang lamban, 'gemuk' dalam hal struktur organisasi, dan terlampau berorientasi pada formalisme aturan ketimbang pencapaian hasil kerja. Sejumlah literatur yang beredar pada awal abad ke-20 menawarkan gagasan reformasi birokrasi dengan meminjam praktik- praktik yang biasanya digunakan dalam organisasi privat. Birokrasi pemerintah diarahkan menjadi organisasi yang bekerja dengan lebih berorientasi pada optimalisasi kinerja, pencapaian hasil yang serba terukur, berupaya mencapai kepuasan pengguna, dan seterusnya yang mengharuskan birokrasi untuk mengubah bentuk, struktur, bahkan budaya organisasinya.

Tulisan ini ingin mengungkapkan bagaimana gagasan kompetisi menjadi instrumen kekuasaan untuk mereformasi cara kerja birokrasi dalam mengelola pembangunan. Untuk itu, digunakan pendekatan diskursus dengan mengungkapkan bagaimana praktik kekuasaan berlangsung dalam mereproduksi klaim kebenaran bagi perubahan identitas birokrasi. Selanjutnya, diungkapkan bagaimana birokrasi membentuk dirinya agar memenuhi kriteria identitas sebagai birokrasi yang kreatif dan inovatif.

\section{METODE}

Tulisan ini menggunakan metode analisis diskursus untuk menganalisis data tekstual konsep kompetisi, rezim knowledge management, dan birokrasi. Kekuasaan produktif bekerja melalui penciptaan klaim kebenaran dalam proses diskursif. Karena itu, unit analisis dalam penelitian ini adalah diskursus yang berupa pernyataan-pernyataan (statements) yang terdapat dalam arsip. Arsip yang dimaksud adalah sistem umum dari formasi dan transformasi pernyataan (Foucault, 2002), antara lain dalam dokumen-dokumen pemerintah, jurnal, pemberitaan, maupun sumber-sumber tertulis lainnya. Arsip-arsip tersebut diperlakukan dan dibaca ulang untuk menemukan relasi antara pernyataan dan tampilan (visible things) yang dibentuk melalui pernyataan tersebut. Dokumen-dokumen tersebut diperlakukan lebih sebagai sumber data utama, sekaligus juga menjadi bahan analisis dalam menguraikan teknologi kekuasaan yang bekerja melalui rezim pendokumentasian. Interpretasinya bukan pada makna di balik narasi dokumen tersebut, tapi pada penyajian data tersebut.

Untuk mengungkap pelembagaan gagasan kompetisi yang membuktikan bahwa ada praktik kekuasaan yang bekerja untuk membentuk perilaku manusia, maka yang perlu diidentifikasi adalah bagaimana klaim kebenaran dihasilkan, realitas apa yang dipermasalahkan sehingga perlu ada intervensi untuk menangani persoalan tersebut. Data yang diperlukan adalah tentang kondisikondisi yang memunculkan kebutuhan akan perubahan, kondisi yang dianggap sebagai masalah, bagaimana masalah itu dikonstruksi, direproduksi, sehingga upaya untuk mengatasinya mendapat pembenaran dalam rangka menyesuaikan dengan perubahan yang dikehendaki. Pelacakan terhadap kondisi-kondisi ini dilakukan melalui pengumpulan data historis, baik yang bersifat primer melalui informan maupun sekunder melalui dokumen dan literatur.

Pertemuan dengan sistem-sistem pengetahuan 
lain juga menjadi indikasi dari berlangsungnya relasi kekuasaan. Sebagai strategic game, relasi kekuasaan bersifat dinamis, lintas sektor, dan multidimensional. Untuk mengungkap praktik kekuasaan sebagai strategic game, dilakukan pelacakan transfer gagasan kompetisi dari berbagai sektor, di mana gagasan itu berkembang dan diterapkan. Dengan melacak transfer gagasan ini, kondisi awal yang memproduksi gagasan kompetisi dapat diketahui, termasuk proses yang menyebabkan gagasan itu mengalami perubahan-perubahan, baik yang berupa keterputusan atau keberlanjutan dari gagasan awal.

Praktik kekuasaan juga dikenali melalui penundukan subjek terhadap rezim atau aturan main yang menjadi bagian dari sistem pengetahuan. Penundukan ini dihasilkan oleh proses normalisasi maupun performativitas (Butler, 1997), di mana tubuh subjek dilatih dan dibiasakan untuk berperilaku seperti dikehendaki rezim. Pengungkapan terhadap proses ini memerlukan data yang terkait dengan berbagai teknologi, baik yang berupa alat, cara, atau prosedur yang dibuat untuk membentuk perilaku subjek. Data tentang hal ini bersumber dari pelacakan terhadap berbagai dokumen tertulis yang memuat prosedur normatif.

\section{HASIL DAN PEMBAHASAN}

Sebagai sebuah praktik sosial, kompetisi telah menjadi bagian dari kehidupan manusia sehari-hari, terutama berkaitan dengan keharusan manusia untuk mengelola sumber-sumber daya yang serba terbatas agar dapat tetap mempertahankan kelangsungan hidupnya. Kendati tampak sebagai perilaku yang alamiah, kompetisi pada kenyataannya berkaitan dengan kemampuan individu untuk memilih strategi yang paling tepat untuk dapat bertahan hidup, sehingga individu kemudian mengembangkan kemampuan-kemampuan tertentu untuk dapat berkompetisi. Kompetisi menjadikan tubuh sebagai sasaran yang harus dibentuk ulang untuk menciptakan individu yang dapat bertahan hidup dan mampu menggunakan seluruh potensi yang ada dalam dirinya. Keberlangsungan hidup individu ditentukan oleh kemampuannya untuk mengenali dirinya, mengetahui tantangan yang dihadapi, dan memanfaatkan kemampuan yang dimilikinya untuk mengatasi tantangan tersebut. Dalam konteks ini, kompetisi menjadi cara pengaturan yang berbeda yang menentukan bagaimana inidividu mengelola dirinya dan hubungan dirinya dengan berbagai hal di luar dirinya.

Foucault (2008) membahas kompetisi sebagai suatu seni memerintah dalam kaitannya dengan kemunculan neoliberalisme. Neoliberalisme tidak sekedar mengatur bagaimana pemerintahan atau aktivitas ekonomi dilakukan, tapi juga menentukan bagaimana cara hidup individu diatur. Dalam kuliahnya tentang biopolitik, Foucault membedakan neoliberalisme dan liberalisme klasik dari karakter aktivitas ekonominya. Berbeda dengan liberalisme klasik yang berfokus pada pertukaran sebagai instrumen utama untuk mengatur relasi sosial antarindividu, neoliberalisme mengembangkan instrumen baru, yakni kompetisi. Meskipun demikian, kedua rezim ini sama-sama menempatkan manusia sebagai makhluk ekonomi yang tunduk pada institusi pasar. Rasionalitas pasar meyakini bahwa individu dapat bertindak otonom dalam mengelola sumber-sumber daya, sehingga menjadi lebih efektif dan efisien. Peran negara berkurang karena perlindungan yang semula disediakan oleh negara melalui institusi hukum, digantikan oleh pengakuan atas hak-hak kepemilikan yang bersifat privat. Institusi pasar dengan rasionalitasnya tersebut tidak hanya menjadi aturan main yang menentukan peran negara, bahkan juga mengarahkan perilaku individu yang dikehendaki.

Bekerjanya mekanisme pasar dalam pengelolaan sumber daya menghendaki agar akses terhadap informasi dibuka seluas mungkin dan untuk mencapai efisiensi, digunakan mekanisme kompetisi. Institusi yang dapat mengelola sumber daya dengan biaya sehemat mungkin tapi mampu mencapai hasil seoptimal mungkin, akan unggul dalam pengelolaan sumber daya. Ia akan memperoleh hak untuk menentukan bagaimana sumber daya tersebut dikelola. Rasionalitas ekonomi inilah yang mengawali masuknya gagasan kompetisi sebagai cara kerja baru bagi birokrasi yang inovatif. Birokrasi sebagai pelaksana fungsi pemerintahan perlu menyesuaikan diri dengan aturan main yang ditentukan oleh rasionalitas ekonomi tersebut.

Kemunculan gagasan kompetisi dalam praktik pembangunan membuka diskursus tentang identitas baru birokrasi. Merujuk pada Deetz (1994), identitas dipahami sebagai penandayang dibentuk, dipertahankan, dan diperkuat dengan membuat pembedaan antara diri (self) dan lain (other). Dekonstruksi identitas birokrasi diawali dengan identifikasi mengenai apa itu subjek, dalam hal ini, apakah birokrasi itu. Pembatasan ini kemudian diikuti dengan penyusunan kategori, mana yang termasuk dalam kategori subjek yang normal (self) dan mana yang bukan (other).

Styhre (2007) membuat 3 (tiga) klasifikasi pemaknaan birokrasi yang selama ini berkembang. Pertama, birokrasi selalu dikesankan secara negatif sebagai organisasi yang tidak efisien, kinerjanya tidak memuaskan publik, dan para anggotanya tidak memiliki pengalaman kerja yang menunjang kompetensinya. Kedua, birokrasi juga sering digambarkan sebagai bentuk organisasi primordial yang kinerjanya buruk. Ketiga, karena birokrasi seringkali diasosiasikan dengan formasi sosial yang menghendaki lingkup intervensi sektor publik yang besar serta administrasi publik yang tertutup terhadap kekuatan pasar dan kompetisi, birokrasi juga sering dikritik sebagai predatory capitalism yang menghalangi munculnya ideologi kemandirian, individualisme, dan jenjang karir berbasis meritokrasi. 
Ketiga klasifikasi tersebut menempatkan birokrasi dalam identitas yang cenderung negatif, sebagai organisasi yang tidak responsif terhadap perubahan. Problematisasi terhadap identitas birokrasi tidak hanya disebabkan oleh kesan negatif yang muncul, tapi juga dari ketunggalan identitas tersebut. Konsep birokrasi sebagai tipe ideal organisasi modern sebagaimana dikemukakan oleh Weber menjadi penyebab ketunggalan identitas birokrasi, sehingga ketika pada praktiknya birokrasi tidak bekerja sebagaimana identitas ideal itu maka kesan negatif yang muncul. Padahal, birokrasi bukanlah entitas yang hanya memiliki identitas tunggal, sehingga seperti juga organisasi lainnya, identitas birokrasi selalu bisa dibentuk ulang untuk merespon berbagai perubahan.

Kesan negatif terhadap sosok birokrasi membentuk klaim kebenaran bahwa birokrasi harus diubah untuk menjadi sosok lain yang sejalan dengan rasionalitas ekonomi pro-pasar. Klaim ini diperkuat dengan berkembangnya berbagai konsep organisasi dan manajemen sektor publik yang mengharuskan birokrasi pemerintahan mengadopsi cara kerja yang umumnya digunakan oleh organisasi-organisasi privat. Kehadiran konsep-konsep akademik ini yang kemudian membentuk rezim atau sistem pengetahuan baru yang menormalisasikan sosok birokrasi pro-pasar sebagai birokrasi modern.

Sebagai organisasi modern, keberadaan birokrasi tetap diperlukan oleh sistem pasar, tapi sistem ini menghendaki birokrasi berubah untuk lebih responsif. Birokrasi sejak awal telah dikonsepsikan sebagai organisasi yang menjalankan dominasi melalui pengetahuan (Weber dalam Casey, 2004), dan dalam kerangka sistem pasar, penguasaan atas pengetahuan inilah yang ingin diubah. Niskanen (dalam Peters, 2002) membangun argumentasinya dengan menggunakan monopoli birokrasi atas informasi sebagai penyebab pemborosan anggaran publik oleh birokrasi. Menurutnya, “...bureau chiefs will use their control of information and their ability to disguise the true costs of producing the public services they provide in order to increase their budgets to points far above the level necessary..." (dalam Peters, 2002). Akibat monopoli informasi tersebut, pengambilan keputusan oleh lembaga legislatif tidak dapat ditentukan secara independen, sehingga untuk mengontrol birokrasi, akses terhadap informasi harus dibuka selebar mungkin pada berbagai pihak. Sistem pasar bekerja efektif ketika asimetri informasi dapat diminimalkan dan penciptaan pengetahuan dapat dilakukan oleh sebanyak mungkin pihak. Dominasi birokrasi atas pengetahuan itulah yang sesungguhnya menjadi sasaran problematisasi dari sistem pasar.

Dalam konteks neoliberalisme yang berkembang pada dekade 1990-an, pengetahuan bahkan menjadi penciri yang membedakan masyarakat industri dengan masyarakat pascaindustri. Masyarakat pascaindustri adalah masyarakat yang menggunakan pengetahuan sebagai basis pengambilan keputusan (Castells, 2004). Pertimbangan yang digunakan untuk menentukan tindakan juga tidak sekedar diorientasikan pada optimalisasi manfaat, tapi seberapa besar resiko yang dapat dikelola. Pengetahuan menjadi sumber daya yang dipakai untuk menghitung resiko, sehingga kemampuan untuk mengelola pengetahuan menjadi hal strategis pada masa ini.

Pengetahuan menjadi sumber daya untuk membentuk pemahaman baru tentang berbagai hal dan menerapkannya pada teknologi, produk, atau proses tertentu. Kapabilitas intelektual dan keterampilan mental menjadi semakin penting bagi penciptaan kesejahteraan, menggantikan keterampilan-keterampilan fisik dan kontrol birokratis atas sumber-sumber daya. Intelektualitas juga menjadi prasyarat penting untuk merespon secara kreatif berbagai kondisi ketidakpastian. Kreativitas ini dihasilkan melalui pengelolaan pengetahuan, yang pada dasarnya mencakup aktivitas-aktivitas penciptaan, penyebaran, dan pemanfaatan pengetahuan (Wikstrom dan Norman dalam Blacker, Crump, dan McDonald, 1998). Karena itu, sumber daya manusia yang dapat melakukan fungsi ini adalah mereka yang mampu menggunakan semaksimal mungkin keunggulan kompetitif dari pengetahuan yang dimilikinya untuk menghasilkan sesuatu yang baru atau berbeda dari yang sudah ada sebelumnya. Drucker (1993) menjelaskan bahwa dinamika ekonomi di negara-negara Barat pada masa sekarang telah bergeser dari ketergantungan pada keterampilan teknis menjadi kemampuan kreatif dari para knowledge workers, yakni people who are able to exploit the competitive advantage that their specialized insights provide (dalam Blacker, Crump, dan McDonald, 1998). Dengan demikian, pengelolaan pengetahuan tidak hanya mencakup aktivitas pengelolaan data, tapi juga pembentukan subjek yang dapat melakukan aktivitasaktivitas tersebut.

Kebutuhan untuk mengelola pengetahuan mensyaratkan adanya kreativitas dan inovasi karena esensi dari pengelolaan pengetahuan adalah kemampuan untuk memaknai data dalam rangka membentuk realitas. Pembentukan realitas adalah proses kreatif yang mensyaratkan individu-individu yang mampu berpikir bebas. Karena itu, struktur birokrasi konvensional yang hirarkhis perlu diubah agar individu-individu tidak lagi terbatasi oleh hirarkhi tersebut. birokrasi didekonstruksi melalui penyebaran diskursus enterpreneurship bureaucracy (Hjorth, 2003), innovative bureaucracy (Styhre, 2007), dan sejenisnya yang menonjolkan sosok birokrasi sebagai organisasi yang bekerja atas dasar dorongan pengetahuan (knowledge-driven organization).

Dengan masuknya knowledge management dalam konteks reformasi birokrasi, tidak hanya menguatkan identitas baru birokrasi yang inovatif, sekaligus membentuk keterampilan baru yang harus dimiliki birokrasi untuk memenuhi identitas tersebut. 
Melalui proses inilah sesungguhnya subjektivasi atau penundukan sebagai operasi kekuasaan berlangsung, di mana birokrasi dilatih untuk melakukan aktivitasaktivitas pengelolaan data.

Untuk mendukung bekerjanya rezim pembangunan berbasis pengetahuan, dibutuhkan sosok birokrasi yang mampu mengelola data dan informasi secara obyektif. Penundukan birokrasi dilakukan melalui standarisasi dan pendisiplinan birokrasi agar patuh pada standar-standar tersebut.

Standarisasi diawali dengan penciptaan standarstandar untuk membentuk kategori normalitas yang baru, yang selanjutnya menentukan bagaimana seharusnya birokrasi melaksanakan perannya dalam praktik pembangunan. Standar didefinisikan sebagai kriteria, ukuran atau patokan dari suatu prosedur, proses, dimensi, perkembangan, kuantitas, kualitas atau waktu yang ditetapkan oleh suatu otoritas, kebiasaan, atau kesepakatan umum sebagai basis perbandingan (Henman dan Dean, 2010). Standar dibuat sebagai model atau acuan untuk membandingkan suatu hal atau perilaku, sehingga menjadi sebuah ukuran baku yang berlaku umum untuk memberi penilaian terhadap hal atau perilaku tersebut. Karena itu, standarisasi sebenarnya adalah proses normalisasi yang bersifat teknis, yang dimaksudkan untuk membentuk pembakuan dari suatu proses atau perilaku.

Pembakuan teknis ini memiliki beberapa fungsi, sebagaimana dinyatakan Henman dan Dean (2010), yakni penyederhanaan (simplification), penyatuan (unification), dan pengkhususan(specification). Fungsi penyederhanaan dilakukan dengan mengurangi kompleksitas dari persoalan yang dihadapi, fungsi penyatuan dilakukan dengan membuat berbagai aspek saling terintegrasi, dan fungsi pengkhususan dilakukan dengan mengembangkan pemahaman yang spesifik tentang berbagai hal. Melalui ketiga fungsi ini, standarisasi menjadi proses diskursif untuk membentuk ulang pemaknaan tentang realitas dan dengan ukuran-ukuran apa realitas itu akan dinyatakan.

Sebagai proses diskursif, standarisasi tidak hanya menghasilkan ukuran-ukuran yang bersifat matematis dalam bentuk angka-angka, tapi juga batasan konseptual tentang realitas. Standar juga menjadi representasi realitas ketika ia melakukan penyederhanaan, penyatuan, dan pengkhususan realitas. Di dalam pembakuan makna, standarisasi membuka berbagai kemungkinan, sekaligus membatasi. Perumusan berbagai prosedur, persyaratan, penilaian, dan format yang harus dipatuhi oleh birokrasi merupakan salahsatu indikasi dari pembatasan. Standarisasi ini membentuk ulang kategori normal dengan menolak normalitas yang ada sebelumnya, sehingga lahir normalitas baru berbasis kompetisi.

Standarisasi ini selanjutnya membentuk keterampilan teknis bagi aparat birokrasi untuk menyajikan data secara rasional. Keterampilan-keterampilaninimenghasilkan pengetahuan baru tentang bagaimana memanfaatkan data untuk menginformasikan capaian kinerja. Di sisi lain, keterampilan dalam mengklasifikasikan data juga melatih birokrasi untuk bekerja secara efisien dalam mendokumentasikan data dan melakukan pencatatan. Keterampilan-keterampilan ini berkontribusi bagi terbentuknya keahlian baru birokrasi dalam mengelola data dan informasi, sekaligus menjadi teknologi untuk mengontrol perilaku birokrasi. Praktik ini membuktikan bahwa standarisasi menjadi praktik kekuasaan yang produktif karena menghasilkan pendisiplinan dan pengetahuan baru yang mendasari perilaku subjek.

Basis data merupakan komponen utama dari rezim knowledge management karena menjadi inti dari bangunan sistem pengetahuan yang mendukung proses pengambilan keputusan, bahkan keseluruhan proses dalam pengelolaan urusan publik ditentukan oleh data yang tersedia dan bagaimana data itu dimaknai sebagai informasi. Struktur dan isi dari basis data, yang mencakup jenis data yang disimpan, cara untuk mengakses data, dan pemanfaatan data akan menentukan cara kerja birokrasi dalam melakukan fungsi pengelolaan sumber daya. Proses ini menghasilkan standarisasi atau pembakuan praktik pengelolaan data sebagai konsekuensi dari penerapan knowledge management itu sendiri, yang mencakup standarisasi tentang jenis data yang disimpan dan disebarluaskan serta prosedur untuk memanfaatkan dan membatasi penggunaan data. Singkatnya, standarisasi ini mengatur pertukaran informasi sebagai kerangka dari pelaksanaan fungsi tertentu.

Sistem basis data menghendaki agar data ditentukan secara tegas batasannya sehingga pemanfaatannya juga dapat disesuaikan dengan fungsi atau kebutuhan organisasi. Knowledge management pada dasarnya merupakan praktik penyederhanaan, penyatuan, dan pengkhususan dari penciptaan informasi dan proses informasi. Standarisasi yang dihasilkan oleh rezim knowledge management berfungsi untuk menyebarkan dan mengkomunikasikan data sebagai unit-unit yang telah ditentukan secara tegas untuk membatasi dan menentukan bagaimana subjek memandang, memahami, bahkan bereaksi terhadap suatu realitas. Proses ini menjadi cerminan dari bekerjanya logika instrumental (Henman dan Dean, 2010).

Aparat birokrasi dibiasakan untuk mengumpulkan data tertentu, menuliskan data tersebut dalam format tertentu, dan menggunakan data tersebut untuk kepentingan yang telah ditentukan sebelumnya. Keseluruhan praktik ini terkesan sederhana, tapi menjadi praktik kekuasaan karena disertai dengan reward dan punishment untuk membentuk kepatuhan. Pada sisi yang lain, klasifikasi dan kategorisasi juga tidak selalu dapat merefleksikan kompleksitas realitas karena makna atas data tersebut dapat bersifat ambigu. Dalam translasi, sejumlah informasi mungkin hilang atau terabaikan. Karena itu, data tidak lagi benar-benar bersifat netral karena sudah dilekati oleh norma-norma tertentu, sehingga pengelolaan data menjadi informasi juga sarat dengan kepentingan-kepentingan yang melatarbelakangi 
produksi pengetahuan dari data dan informasi tersebut. Data diolah sebagai informasi yang akan digunakan untuk menguatkan klaim kebenaran yang memberikan justifikasi bagi subjektivasi. Norma yang ingin dilembagakan adalah norma kompetisi yang dirasionalisasikan melalui logika akademik.

Knowledge management tidak hanya menentukan jenis dan struktur informasi yang dianggap bermanfaat bagi perencanaan pembangunan, tapi juga menentukan informasi apa yang tidak penting atau bisa diabaikan. Penentuan pilihan ini merupakan praktik politik karena berkaitan dengan kepentingan memperkuat sistem pengetahuan. Ini menjadi teknologi kekuasaan untuk memilah mana pengetahuan yang sejalan dengan rasionalitas pembangunan manusia dan mana yang tidak. Jadi, di balik klaim obyektivitas dalam mengelola sumber daya, sesungguhnya ada pemihakan terhadap kepentingan tertentu, yakni kepentingan untuk memperkuat logika kompetisi sebagai pilar utama reformasi birokrasi.

\section{SIMPULAN}

Praktik standarisasi yang dihasilkan melalui knowledge management memunculkan subjektivasi baru di mana birokrasi tunduk pada pembakuan pengelolaan data dan informasi. Implikasi dari standarisasi dalam rezim knowledge management terhadap cara kerja birokrasi adalah: Pertama, sistem kerja berubah karena peran birokratyang semulaharus memilahdokumenberdasarkan kategori konvensional harus menyesuaikan diri dengan standar baru; Kedua, sistem pengelolaan informasi dalam rezim knowledge management justru menerapkan cara-cara yang lebih ketat untuk menstandarisasi data, sehingga diskresi kewenangan untuk menginterpretasi data di tingkat pelaksana juga berkurang. Aparat birokrasi di tatanan pelaksana semula mengambil keputusan berdasarkan kerangka acuan normatif dan memanfaatkan data sebagai pendukung. Pada cara kerja baru yang dibawa oleh knowledge management, pengambilan keputusan terintegrasi dengan sistem data sehingga basis pengambilan keputusan bukanlah kerangka normatif, tapi informasi yang dihasilkan oleh sistem data tersebut; Ketiga, pergeseran kepakaran teknis yang memunculkan jenis kepakaran baru. Standarisasi dalam pengelolaan informasi memunculkan pertanyaan tentang siapa yang mendesain sistem informasi dan untuk siapa sistem tersebut diarahkan. Proses ini mengubah pola relasi kekuasaan dalam birokrasi karena munculnya kepakaran baru sebagai otoritas yang memproduksi pengetahuan dalam tubuh birokrasi. Ketika penentuan standar data hanya menjadi domain staf teknis, maka aktivitas konstruksi pengetahuan akan tereduksi menjadi proses teknis, padahal pengetahuan tersebut nantinya akan dipakai untuk mendisiplin subjek. Di sini muncul isu tentang dimensi etik dalam pengelolaan data dan konstruksi pengetahuan; Keempat, data menentukan bagaimana organisasi akan dikelola. Rezim knowledge management membentuk ulang cara mengelola organisasi karena di dalamnya terdapat berbagai sistem kategorisasi yang menentukan bagaimana realitas dipersepsi dan ditanggapi. Pengetahuan ini tidak lagi bersifat lokal dan parsial, tapi telah terformalkan dan bersifat universal karena memberi gambaran umum tentang organisasi maupun realitas yang dianggap penting bagi organisasi. Standarisasi dalam pengelolaan informasi yang menjadi inti dari aktivitas knowledge management seringkali diasumsikan sebagai tahap penting dari penerapan New Public Management karena menandai pergeseran cara pengelolaan organisasi ke arah pengukuranpengukuran yang terstandarisasikan, khususnya melalui pengembangan indikator-indikator kinerja. Meskipun penetapan standar-standar ini bersifat sentralistik, tapi kebebasan dan inovasi akan berkembang ketika ada kebebasan untuk melakukan berbagai upaya dalam mencapai indikator tersebut. Kondisi ini memunculkan paradoks tersendiri karena standarisasi formal justru menghasilkan strategi-strategi yang tidak terstandarkan untuk mencapai indikator-indikator tersebut; Kelima, rezim knowledge management menentukan bentukbentuk pengaturan atas cara kerja birokrasi yang menjadi target atau sasaran pengaturan. Basis data memberikan informasi tentang berbagai hal baru tentang suatu realitas, yang sebelumnya tidak dianggap penting, atau bahkan dianggap tidak ada karena datanya tidak tersedia. Ketika knowledge management diterapkan, data dapat dimaknai dengan cara berbeda sehingga sistem kategori baru dapat diciptakan untuk menangani suatu masalah.

Standarisasi pengelolaan informasi melalui rezim knowledge management mencakup pula kategorisasi yang memilah-milah subjek berdasarkan cara penanganannya. Dengan rezim ini, setiap subjek diperlakukan berbeda tapi tidak secara khusus sebagai individu. Pengetahuan dipakai untuk menentukan intervensi atas diri birokrat, tapi tetap mengacu pada standar-standar yang dibakukan sebagai ukuran normalitas. Karena itu, praktik ini sesungguhnya tidak mengarah pada penciptaan lokalitas, tapi justru universalitas atau penyeragaman perlakuan bagi birokrasi sebagai subjek.

\section{DAFTAR PUSTAKA}

Blacker, F., Crump, N., \& McDonald, S. 1998. Knowledge, organizations, and competition. Dalam J. R. Georg vo Krogh, Knowing in firms: Understanding, managing, and measuring knowledge (pp. 67-86). London: Sage Publications Ltd.

Butler, J. 1997. Excitable Speech: A Politics of the Performative.

Casey, C. 2004. Bureaucracy re-enchanted? Spirit, experts, and authority in organizations. Organization, 11(1), 59-79. doi:10.1177/1350508404039658 
Castells, M. 2004. The network society: A Cross-cultural perspective. UK: Edward Elgar Publishing Limited.

Deetz, S. 1994. The micro-politics of identity formation in the workplace: The case of knowledge intensive firms. Human Studies, 17(1), 23-44.

Foucault, M. 2002. Power/knowledge: Wacana kuasa/ pengetahuan. (Y. Santosa, Penerj.) Yogyakarta: Bentang Budaya.

Foucault, M. 2002. Pengetahuan dan Metode: Karyakarya Penting Foucault. Yogyakarta: Jalasutra.

Foucault, M. 2008. The Birth of biopolitics: Lectures at the Collège de France, 1978-1979. (G. Burchell, Penerj.) New York: Palgrave MacMillan.

Henman, P. \& Mitchell, D. 2010. E-Government and the production of standardized individuality. Dalam S. K. V. Higgins, Calculating the social: Standards and the re-configuration of governance (pp. 77 93). Basingstoke: Palgrave Macmillan.

Hjorth, D. 2003. Rewriting entrepreneurship - for a new perspective on organisational creativity. Copenhagen, Denmark: Copenhagen Business School Press.

Peters, B. G. 2002. The politics of bureaucracy, fifth edition. London \& New York: Routledge.

Pieterse, J. N. 2010. Development theory, deconstructions/ reconstructions. Second Edition. London: Sage Publications Inc.

Rose, N., O’Malley, P., \& Valverde, M. 2006. Governmentality. Annual Reviews Law \& Social Science, 2, 83-104.

Styhre,A. 2007. The innovative bureaucracy: Bureaucracy in an age of fluidity. London: Routledge 